\title{
Accessing bank finance in relation to human capital, gender and race among SMMEs in a developing economy
}

\author{
P. Brijlal and B. Yan
}

\begin{abstract}
Small, Micro and Medium-sized Enterprises (SMMEs) contribute to the national economy significantly. However, many SMMEs have difficulties in accessing bank finance due to the lower level of their human capital and scarce financial resources in the context of developing economies. This study aims to investigate the key factors of human capital and associated issues with access to bank finance from gender and race perspectives. A survey design combined qualitative and quantitative research approaches were employed in this study. Data were collected through a self-administered questionnaire and a number of interviews. A group of SMME owners $(n=532)$ were randomly selected from the Western Cape, South Africa. The findings demonstrated that the human capital and gender of SMMEs is not strongly associated with success in securing bank finance. From a race perspective, white entrepreneurs are more likely to be approved for bank finance than other race groups.
\end{abstract}

\section{INTRODUCTION}

Bank finance is critical to the development of Small, Micro and Medium-sized Enterprises (SMMEs) [1, 2]. Research shows that financial capital input levels are strong determinants of a new venture's survival prospects [3, 4] and growth [5]. A number of studies addressed the relevance of human capital to bank finance. It includes education, business training, first business, multiple ownership, management experience and work experience $[6,7,8,9$, $10,11,12]$. Hence, human capital is critical initial 'endowments' which shape the entrepreneur's aspirations and choices about the strategic direction of the business [13, 14]. Prior to 1994, South Africa was a developing country governed by apartheid policies which resulted in dividing the various population groups. In 1994, it became a democratic nation, popularly referred to as the 'rainbow nation'. The labyrinth of apartheid laws and policies in South Africa served to perpetuate a white labour and political aristocracy, denying the black race group, which then comprised the coloured, Indian and African groups, the opportunity to participate fully in the economy. About $80 \%$ of the South African population is made up of black Africans; most of them can be classified as poor [15] with an official unemployment rate of estimate of 24.7\% [16]. According to Statistics South Africa (2011), Africans are in the majority, making up $79.2 \%$ of the population; coloured and white people each make up $8.9 \%$ of the total; and the Indian, Asian, and other population 
counts $3 \%$. Recognition is also growing that women make a vital contribution to economic development [15]. Yet gender continues to have a negative impact on such development on the African continent [17]. However, lack of financial capital will lead to a great impediment to entrepreneurial growth in developing economies, in which the financial system is transforming towards market governance. Thus, this study looks into the key factors of human capital associated with gender and race issues in accessing bank finance in the context of South Africa.

\section{A. Accessing Bank Finance: Human Capital}

Human capital derives from investments in formal education, work experiences and training [11], also includes training courses that are not part of traditional formal educational structures. On the demand side, higher levels of education and longer previous managerial experience result in the accumulation of explicit knowledge and entrepreneurial skills [18]. Similarly, entrepreneurs with higher levels of education and work experience are likely to be more efficient in seeking, gathering and analysing information about the availability of opportunities including accessing financial resources [9].

On the supply side, the level of education may serve as a proxy for persistence, motivation and self-discipline, which impacts favourably on the impressions of financial capital providers [10]. Reference [3] shows that a college education improves access to debt capital, most directly for commercial bank borrowers. Small business owners with higher educational backgrounds have a higher probability of choosing external sources of funds in the form of bank loans [8]. Reference [7] finds that education made little difference to sources of finance, except that those educated up to Grade 12 (A level) more frequently used friends and family and re-mortgaged their homes, and that graduates had the least difficulty in raising finance. Some evidences were found that education was positively related to external loans [10, 19]. In addition, business owners with higher levels of education were significantly less likely to have applied for a loan within the previous three years of the start of a business operation [10]. First, education is linked with business performance, implying that more highly educated owners operate more profitable businesses. Second, more highly educated owners may make better use of trade credit as a source of financing, thus reducing their reliance on interest-bearing loans.

\section{B. Accessing Bank Finance: Gender and Race}

In relation to gender, despite the growing body of literature on women-owned businesses, their financing strategies and the relationship of financing to growth and performance [11, 20], extant research has not established a set of relationships or patterns that would be unequivocally attributable to gender. Treatments of the effects of gender and race on the access to entrepreneurial financing in the context of developing economies, in particular, have been limited. In development terms, South Africa is classified as a developing nation [21]. It is regarded as having a productive and industrialised economy. 
South Africa's own economic transition into the new millennium has affected men and women differently. Reference [17] highlights the fact that women still do not have equal economic rights and access to resources such as finance. Under these conditions, they are unable to take full advantage of the economic opportunities presented by transition. The International Finance Corporation maintains that, while access to resources such as financial services continues to be largely racially defined, the gender gap between men and women persists, and is likely to grow unless special efforts are undertaken to address the underlying issues [22].

\section{Proposed Model and Hypothesis Development}

Securing bank finance is influenced by the human capital variables of the entrepreneur $[11,23]$. Business owners' experience and educational levels may provide signals of a better human capital [24]. Thus, the better the human capital, the greater the more likely the start-up of an enterprise, its growth and expansion, and consequently its access to financial capital. In South Africa, during the apartheid era, race and gender had an influence on the success rate of the bank application process. Studies showed that women start their businesses with smaller amounts of financial capital and are less likely to raise finance from external sources $[25,26]$.

Based on the relevant literatures, the key factors of human capital, gender and race issues were embedded into the development of the proposed model (Fig.1) and the hypotheses $\left(H^{1}-H^{3}\right)$ below:

$H^{1}$ : Business owner's human capital is positively related to securing bank finance.

$H^{2}$ : Male and female business owners are equally likely to be successful in their applications for bank finance.

$H^{3}$ : Black and white business owners are equally likely to be successful in their applications for bank finance.

\section{METHODOLOGY}

This study employed a quantitative method, using exploratory and descriptive research. Based on the nature of the study, the survey method was found to be the most convenient. The target population was SMME owners who were operating in the main trading areas of Cape Town Central, Bellville, Parow, Mitchells Plain, Wynberg, and Goodwood in this study. This could be generalisable to the Western Cape, as most SMMES are located in these areas. A self-administered questionnaire was developed through the key factors of human capital (education, business training, work experience, previous ownership and work experience and multiple-ownership) that were derived from the literature. These factors were coded as variables as Var1-Var6 which are used to determine the accessibility in securing bank finance. Data were randomly collected from 532 SMME owners. Data 
were then analysed through SPSS statistical software to determine the descriptive results, Chi square value and regression analyses.

\section{RESULTS AND DISCUSSION \\ A. Human Capital Variables affecting Bank Finance}

Table I showed the human capital variables were cross-tabulated with bank application and success to establish if there were associations between human capital variables and bank finance application and success in bank application. For example, $51 \%$ of the bank applicants were educated whereas $49 \%$ were uneducated; $83 \%$ were successful in bank application, while $70 \%$ were unsuccessful (Var1). Based on p-value, the variables Var1, Var2, Var5, and Var6 were not significant, although being educated contributed to the success of bank application.

Based on the Table I, both first-time business owners (Var3) and owning other business (Var4) are significant $(\mathrm{p}<0.05), 77 \%$ of the total bank applications were from first-time business owners and $23 \%$ were from non-first- time owners; $78 \%$ of first-time owners, compared to $73 \%$ who were not first-time owners (Var3), were successful in their bank applications.

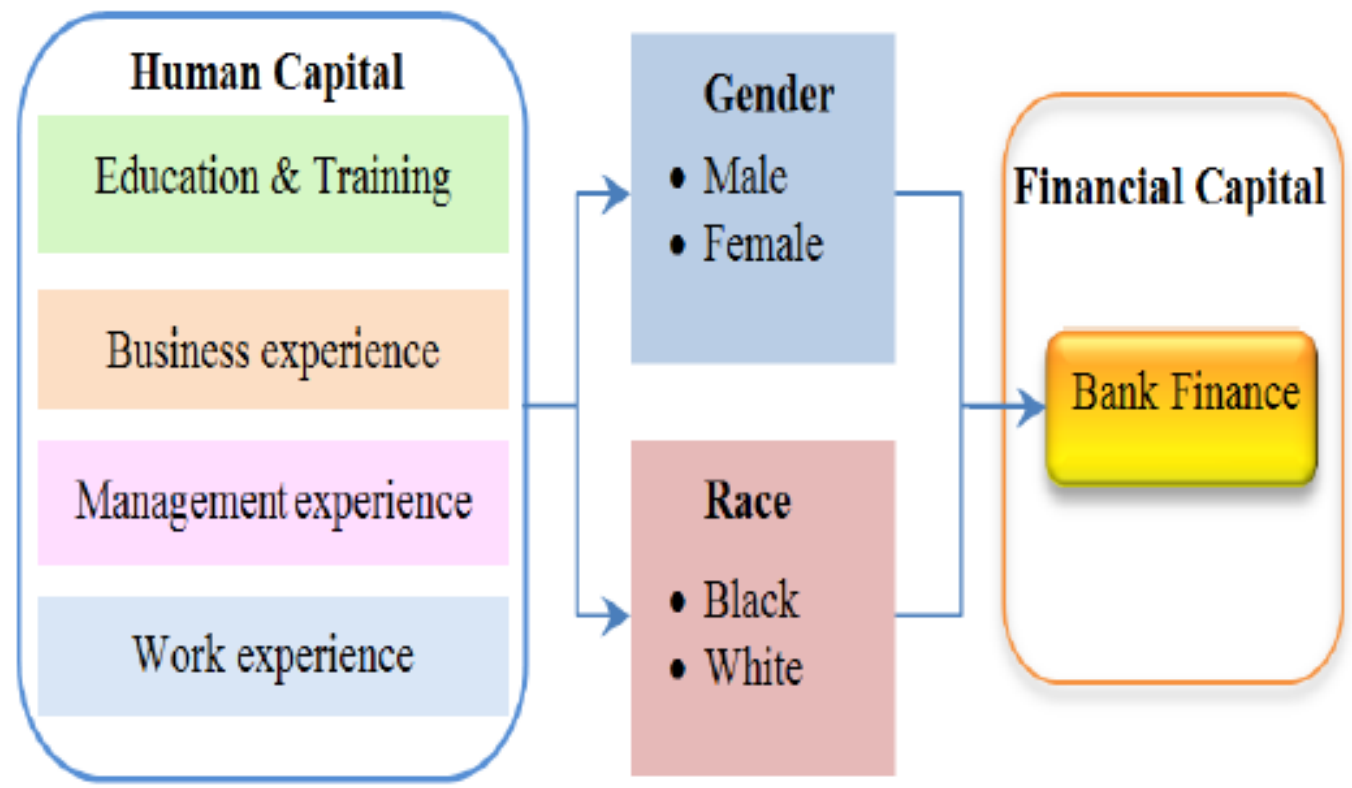

Fig.1. Human capital, gender and race in accessing bank finance 
TABLE I

\section{HUMAN CAPITAL VARIABLES AFFECTING BANK FINANCE}

\begin{tabular}{|c|c|c|c|c|c|c|c|c|}
\hline \multirow{2}{*}{ Var. } & \multicolumn{4}{|c|}{ Bank application } & \multicolumn{4}{|c|}{ Bank success } \\
\hline & $\mathrm{N}$ & No & $\mathrm{N}$ & Yes & $\mathrm{N}$ & No & $\mathrm{N}$ & Yes \\
\hline Var1 & 72 & $49 \%$ & 74 & $51 \%$ & 50 & $70 \%$ & 61 & $83 \%$ \\
\hline Var2 & 77 & $53 \%$ & 69 & $47 \%$ & 60 & $78 \%$ & 52 & $75 \%$ \\
\hline Var3 & 34 & $23 \% *$ & 112 & $77 \% *$ & 24 & $73 \% *$ & 87 & $78 \% *$ \\
\hline Var4 & 57 & $39 \% *$ & 89 & $61 \% *$ & 45 & $79 \% *$ & 67 & $75 \%{ }^{*}$ \\
\hline Var5 & 74 & $51 \%$ & 72 & $49 \%$ & 56 & $76 \%$ & 58 & $80 \%$ \\
\hline Var6 & 31 & $21 \%$ & 115 & $79 \%$ & 23 & $73 \%$ & 90 & $78 \%$ \\
\hline
\end{tabular}

${ }^{*} p<0.05$

TABLE II

BANK FINANCE FROM GENDER AND RACE PERSPECTIVES

\begin{tabular}{|c|c|c|c|c|c|c|c|c|c|}
\hline & \multicolumn{4}{|c|}{ Gender } & \multicolumn{4}{|c|}{ Race } & \\
\hline Bank apply & \multicolumn{2}{|c|}{ Male } & \multicolumn{2}{|c|}{ Female } & \multicolumn{2}{|c|}{ Black } & \multicolumn{2}{|c|}{ White } & Total \\
\hline Yes & 112 & $32 \% *$ & 34 & $19 \% *$ & 102 & $27 \%$ & 44 & $29 \%$ & $27 \%$ \\
\hline No & 240 & $68 \% *$ & 146 & $81 \% *$ & 282 & $73 \%$ & 104 & $71 \%$ & $73 \%$ \\
\hline Total & 352 & $100 \%$ & 180 & $100 \%$ & 384 & $100 \%$ & 148 & $100 \%$ & $100 \%$ \\
\hline Success in application & \multicolumn{2}{|c|}{ Male } & \multicolumn{2}{|c|}{ Female } & \multicolumn{2}{|c|}{ Black } & \multicolumn{2}{|c|}{ White } & Total \\
\hline Yes & 85 & $76 \%$ & 27 & $79 \%$ & 71 & $69 \% *$ & 41 & $93 \% *$ & $79 \%$ \\
\hline No & 27 & $24 \%$ & 7 & $21 \%$ & 31 & $31 \%$ & 3 & $7 \% *$ & $21 \%$ \\
\hline Total & 107 & $100 \%$ & 34 & $100 \%$ & 102 & $100 \%$ & 44 & $100 \%$ & $100 \%$ \\
\hline
\end{tabular}

${ }^{*} p<0.05$

TABLE III

HUMAN CAPITAL AND FINANCIAL CAPITAL

\begin{tabular}{|l|c|c|c|c|c|c|c|c|}
\hline \multirow{2}{*}{$\begin{array}{l}\text { Human } \\
\text { Capital }\end{array}$} & \multicolumn{4}{|c|}{ Model 1(bank application) } & \multicolumn{4}{c|}{ Model 2 (success) } \\
\cline { 2 - 10 } & \multicolumn{3}{|c|}{ Bank Apply } & \multicolumn{4}{c|}{ Bank Success } \\
\hline & B & S.E. & Wald & Exp(B) & B & S.E. & Wald & Exp(B) \\
\hline Var1 & -.043 & .095 & .203 & .958 & -.002 & .104 & .000 & .998 \\
\hline Var2 & -.026 & .211 & .015 & .975 & -.112 & .230 & .239 & .894 \\
\hline Var3 & .527 & .237 & 4.964 & $1.694^{*}$ & .641 & .264 & 5.904 & $1.899^{*}$ \\
\hline Var14 & .676 & .203 & 11.068 & $1.966^{* *}$ & .549 & .222 & 6.131 & $1.731^{*}$ \\
\hline Var5 & -.078 & .220 & .125 & .925 & .187 & .239 & .614 & 1.206 \\
\hline Var6 & .245 & .256 & .916 & 1.277 & .211 & .284 & .549 & 1.234 \\
\hline Constant & -1.740 & .392 & 19.687 & .176 & -2.287 & .438 & 27.213 & .102 \\
\hline
\end{tabular}




\section{A. Bank Finance from Gender and Race Perspectives}

Respondents were required to indicate if they had applied for a bank loan during the past three years and to indicate whether they had been successful in their most recent application.

Table II shows the results from a gender perspective and a race perspective. $27 \%$ of the total respondents applied for a bank loan. A significantly higher proportion of males (32\%) than females (19\%) applied for bank loans ( $\mathrm{p}<0.05)$.

These results indicate that first-time owners were more likely to apply and be successful in securing loans than non-first-time owners. $61 \%$ of the bank applicants who own other business, while 39\% did not own other business (Var4); the bank application success rate was $75 \%$ for respondents who owned other business, compared to $79 \%$ of the subjects not owning other business. This shows that those who did not have ownership in other business were more likely to apply and be successful in securing loans than those who had ownership in other business. Owners of one business were thus more likely to apply successfully for bank finance than those who had multiple-ownership.

\section{B. Bank Finance from Gender and Race Perspectives}

Respondents were required to indicate if they had applied for a bank loan during the past three years and to indicate whether they had been successful in their most recent application.

Table II shows the results from a gender perspective and a race perspective. $27 \%$ of the total respondents applied for a bank loan. A significantly higher proportion of males (32\%) than females (19\%) applied for bank loans ( $\mathrm{p}<0.05)$.

From a race perspective, the application rate for black SMME owners was similar to that for white SMME owners. Thus, there was no significant difference between the race groups in terms of bank application. In terms of success rate, $93 \%$ of the white entrepreneurs were successful, compared with $69 \%$ of black entrepreneurs. White entrepreneurs are thus more likely to be successful in bank applications compared to black entrepreneurs. Human capital variables were regressed to assess which variables affected the likelihood of applying for bank finance and resulting in success, as shown in Table III. The independent variables were level of education, business training, first business, and owner of other business/es, previous management experience and previous work experience.

In Table III, Models 1 and 2, containing all the predictors, were statistically significant $\left[X^{2}(6, \mathrm{~N}=532)=18.275, \mathrm{p}=0.006\right]$ and Model $2\left[X^{2}(6, \mathrm{~N}=532)=13.851, \mathrm{p}=0.031\right]$ indicated that the models were able to distinguish between the human capital variables that contributed to applying for bank finance and success in bank application. As shown in the Table III, two independent variables made a unique, statistically significant contribution to the model (first-time owner and owner of other businesses). The strongest 
predictor of bank application was 'owning other business/es', indicating that respondents who owned other business/s were 1.97 times more likely to apply for bank loans than those who did not have other businesses, controlling for all factors in the model. The strongest predictor of success in bank application was 'first-time owner', indicating that respondents who were first-time business owners were 1.90 times more likely to be successful in their bank loan applications than those who were not first-time owners, controlling for all factors in the model.

\section{Results of the hypotheses}

$H^{1}$ : Business owner's human capital is positively related to securing bank finance.

Only three human capital variables, namely 'first- time business owner', 'owner of other business/es' and 'management experience' were associated with securing bank finance. In particular, education was not associated with success in securing such finance. Thus it can be concluded that human capital is not strongly associated with securing bank finance.

$H^{2}$ : Male and female business owners are equally likely to be successful in their applications for bank finance.

Although male entrepreneurs had a stronger bank relationship than females, the success of bank applications was not significantly different between male and female entrepreneurs thus supporting this hypothesis.

$H^{3}$ : Black and white business owners are equally likely to be successful in their applications for bank finance.

There were no differences in the bank application rates from a race perspective. However, a significantly higher percentage of white entrepreneurs than black entrepreneurs were successful in their bank applications, thus not supporting this hypothesis.

\section{CONCLUSION}

In general, differences in human capital variables were noted from a gender and a race perspective. A quarter SMMEs sourced finance from a bank. Being educated, a first-time business owner and owning one business were associated with bank application and success in the bank application process. A higher proportion of males than females applied for bank finance and it is found that gender is independent of success in bank application.

From a race perspective, the bank application rates were similar. However, white entrepreneurs were more successful than black entrepreneurs in securing finance from a bank. The results suggest that white entrepreneurs have a greater chance of success than black entrepreneurs. Business training, management experience and previous work experience were not associated with bank application and success in obtaining bank finance. Hence human capital of an entrepreneur was not positively associated with success in bank application. 
In conclusion, financial capital was not influenced by gender. Male and female owners were equally likely to be successful in the bank application process. However financial capital was influenced by race; white entrepreneurs were more likely than black entrepreneurs to be successful in their applications for bank loans.

\section{REFERENCES}

[1] G. Bertocco, "The characteristics of monetary economics: a Keynes-Schumpeter approach", Cambridge Journal of Economics, vol. 31, no. 1, pp. 101-122, 2007.

[2] M. Feakins, "Commercial banks' lending to SMEs in Poland", Small Business Economics, vol. 1, no. 8, pp. 51- 70, 2005.

[3] T. Bates, "Entrepreneur human capital inputs and small business longevity", The Review of Economics and Statistics, vol. 72, no. 4, pp. 551-559, 1990.

[4] A. Cooper, F. J. Gimeno, C. Woo, "Initial human and financial capital as predictors of new venture performance”, Journal of Business Venturing, no. 9, pp. 371-395, 1994.

[5] J. Wiklund, D. Shepherd, "Aspiring for, and achieving growth: The moderating role of resource and opportunities", Journal of Management studies, vol.40, no.8, pp. 19191941, 2003.

[6] O. Fatoki, "Enhancing Access to External Finance for New Micro-enterprises in South Africa", Journal of Economics, vol. 5, no. 1, pp.1-6, 2014.

[7] D. Irwin, J. M. Scott, "Barriers faced by SMEs in raising bank finance", International Journal of Entrepreneurial Behavior and Research, vol. 16, no. 3, pp. 245-259, 2010.

[8] G. H. Gebru, "Financing preferences of micro and small enterprise owners in Tigray: Does POH hold?” Journal of Small Business and Enterprise Development, vol. 16, no. 2, pp. 322-334, 2009.

[9] D. P. Forbes, "Managerial determinants of decision speed in new ventures", Strategic Management Journal, vol. 46, no. 3, pp. 355- 366, 2005.

[10] S. Coleman, "Access to debt capital for women and minority-owned small firms: Does educational attainment have an impact?" Journal of Developmental Entrepreneurship, vol. 9, no. 2, pp. 127-143, 2004.

[11] N. M. Carter, C. G. Brush, P. G. Greene, E. Gatewood, M. M. Hart, "Women entrepreneurs who break through the equity financing: the influence of human, social and financial capital", Venture Capital, vol. 5, no. 1, pp. 1-28, 2003.

[12] D. Smallbone, F. Welter, "The distinctiveness of entrepreneurship in transition economies", Small Business Economics, vol. 16, no. 4, pp. 249-262, 2001.

[13] I. M. Manev, B. S. Gyoshev, T. S. Manolova, "The role of human and social capital and entrepreneurial orientation for small business performance in a transitional economy", International Journal of Innovation and Entrepreneurship Management, vol. 5, no.3/4, pp. 298-318, 2005.

[14] P. Greene, C. Brush, T. Brown, "Resource configurations in new ventures: Relationships to owner and company characteristics", Journal of Small Business Strategy, vol. 8, pp. 2540, 1997.

[15] Statistics South Africa, "Census South Africa 2011", [Online]:http://www.statssa.gov.za/census.2011/default.asp.[Accessed on 8 March 2013], 2011. 
[16] Statistics South Africa, "Census South Africa 2013", [Online]:http://www.statssa.gov.za/census.2013/default.asp. [Accessed on 6 June 2014], 2013. [17] SAWEN, 2005, "South African women entrepreneurs: a burgeoning force in our economy, a special report. South Africa”,[online]:http://www.docstoc.com/docs/26459090/South-African-Womenentrepreneurs. [Accessed on 2 May 2009].

[18] P. Davidsson, B. Honig, "The role of human and social capital among nascent entrepreneurs", Journal of Business Venturing, vol. 18, no. 3, pp. 301-331, 2003.

[19] S. Coleman, R. Cohn, "Small firm use of financial leverage: Evidence from 1993 national survey of small business finance", Journal of Business Entrepreneurship, vol. 12, no. 3, pp.81-98, 2000.

[20] J. E. Gatewood, N. M. Carter, C. G. Brush, G. P. Green, M. M. Hart, "Women entrepreneurs, their ventures and the venture capital industry, an annotated bibliography". Report 2003 (vol. 1): Stockholm.

[21] World Bank, 2008, "South African country brief", [Online]:http://siteresource.worldbank.org/GILDSOUTHAFRICA/insolvency\%2olaw [Accessed: 16 May 2009].

[22] International Finance Corporation (IFC), "Access to finance for women entrepreneurs in South Africa", Johannesburg, 2006.

[23] T. S. Manolova, I. M. Manev, N. M. Carter, B. S. Gyoshev, "Breaking the family and friends' circle: Predictors of external financing usage among men and women entrepreneurs in a transitional economy", Venture capital, vol. 8, no. 2, pp. 109-132, 2006. [24] D. J. Storey, "Understanding business sector", Emea: Thomson learning: Cengage, 1994.

[25] R. W. Fairlie, A. M. Robb, "Gender differences in business performance: Evidence from the characteristics of business owners' survey”, Small Business Economics, no. 33, pp. 375-395, 2009.

[26] C. Constattinidis, A. Cornet, S. Asandei, "Financing of women-owned ventures: The impact of gender and other owner and firm related variables", Venture Capital, vol. 8, no. 20, pp. 133-157, 2006. 